\title{
SCIENCE AND EDUCATION IN THE BUKHARA EMIRATE AT THE END OF THE 19TH - BEGINNING OF THE 20TH CENTURIES
}

\section{Zebiniso Bozorovna Nasullayeva}

Teacher Of History Kagan District 16 School, Uzbekistan

Kamola Ibratovna Yodgorova

Kagan District Teacher At Specialized State General Education School № 21 Uzbekistan

\section{ABSTRACT}

In the article socio-economic and cultural life of the Emirate of Bukhara of the late 19th and early 20th centuries is revealed. The order of the state system, the beginning of working class formation, the influence of the Russian protectorate on the further socio-economic life of the country is disclosed.

KEYWORDS: - Emirate; capitalist system; state; khanate; dynasty; manghits; representative; protectorate; monarchy; slavery; dynasty; territory; type; nation; Islam; clergy; development; artisans.

\section{INTRODUCTION}

How often we forget the history of our land. And the purpose of my article is a brief overview of the social system of Bukhara at the end of the 19 th and beginning of the 20th centuries. Throughout its development, the Bukhara Emirate was a monarchy of the absolutist type. It included vast parts of the territory of modern Uzbekistan, Tajikistan and Turkmenistan, namely Bukhara, Kashkadarya, Surkhandarya, Navoi, Kulyab, Khatlon, GornoBadakhshchansk and two districts of Samarkand and Chardzhou regions. State administration here had a structure where institutions of power traditional for the Muslim East (monarch - cabinet of ministers - governors of provinces - judges) were intertwined with the experience of ruling previous Bukhara dynasties (Samanids, Karakhanids, Sheibanids, Ashtarkhanids).

The order of the state structure of the emirate was as follows: kushbegi (first minister), kozi - kalon (chief judge), rais (guardian of order and mayor of the capital), divanbegi (chief of the office), zakotchi (leading taxes), lashkarboshi (commander of the 
CURRENT RESEARCH JOURNAL OF PHILOLOGICAL SCIENCES 2(12):

108-112, December 2021

DOI: https://doi.org/10.37547/philological-crjps-02-12-23

ISSN 2767-3758

(C)2021 Master Journals

Crossref do

gil Google

Accepted15th December, 2021 \& Published 20 ${ }^{\text {th }}$ December, 2021

troops) were subordinate to the emir. , mirshab (chief of police). The beks, which were the main administrative units, were ruled by beks, kazii (judges), respectively. [1]

Representatives of the ruler in the 18-20 centuries. the Mangit dynasties held the most important government posts, played a decisive role in the bureaucratic apparatus and the army. They also held in their hands the levers of economic life, disposed of most of the land and pastures, water sources, and took part in major trade operations. The latter were not only the rulers of the state, but also the main clerics, thus personifying the pinnacle of the monarchy of a feudal - theocratic nature. After the emir, the next most important clerical titles in the emirate were mufti, alam (ulema), imams, qori (readers of the Qur'an), etc. [2]

It should be recalled that about 75 thousand people lived in the ancient city by the 20th century. In addition to representatives of the indigenous nationality, Tajiks, Iranians, Arabs, Turkmens, Indians lived here; Bukharian Jews and other nationalities. It must be admitted that the dominant Islam and the Muslim clergy as a whole could and did save the multilingual city from interethnic strife; moreover, Islam here acted as a guarantor of stability and harmony in society.

\section{THE MAIN FINDINGS AND RESULTS}

It follows that this order has been tested and legalized for many centuries, sanctified by Islam and legalized by the Shariah, has proven its ability to protect the monarchy from the attack of internal and external enemies, and practically did not change. As for the economy in the emirate, it was mainly agricultural, land ownership served as the basis for the dominance of large landowners. The majority of the population, respectively, were farmers (dekhkans), cattle breeders (Chorvadors) and urban artisans (kosibs).

There were three types of feudal ownership of the means of production: state (amlak), private (mulk), and vakuf.

The most important element in the social structure of society in the late XIX and early XX centuries. were artisans who represented the only trade - the production group of the population, which subsequently played a huge role in the export of the emirate. In Bukhara, there were about a hundred independent branches of crafts. Workers of numerous small workshops processed metals, fiber (silk, cotton), leather, made clothes, food products, various household items, and were engaged in the construction of buildings. The transformation of handicrafts into commodity production in the Middle Ages, in turn, contributed to the strengthening of the position of Bukhara, the creation of a crossroads of caravan trade routes connecting Central Asia, on the one hand, with Iran, Afghanistan and India, and on the other, with Russia.

In addition, duos were included in the statutes, the reading of which was the duty of artisans at the beginning of work and in its different periods. All artisans were obliged to obey the foremen, the foreman and the owner of the workshop. Violation of the rules was punishable by a monetary penalty in favor of the foreman or headman. In general, the artisans were completely subordinate to the clergy.

In Bukhara in the nineteenth century. there were several hundred mosques built in the traditions of ancient pre-Muslim and Muslim architecture. They were one-two-story and with upper galleries. There were about 170 large and small madrasahs in the city, in which they received Muslim education and taught up to 10 thousand teachers, subdivided into categories: mullobachi (novice teachers), mudarris (experienced teachers), imams (higher spiritual 
CURRENT RESEARCH JOURNAL OF PHILOLOGICAL SCIENCES 2(12):

108-112, December 2021

DOI: https://doi.org/10.37547/philological-crjps-02-12-23

ISSN 2767-3758

(C)2021 Master Journals

Crossref do

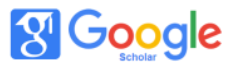

Accepted15 th December, 2021 \& Published 20 th December, 2021

ministers) and ulema - scientists. lawyers who had the right to issue an opinion (fatwa) on any actions of the ruler of the country.

Bukhara was considered the center of enlightenment throughout Central Asia. Students from Khiva, Kokand, Samarkand, Kazan, Orenburg and other cities of the Muslim world came here to study theological sciences. Samarkand has lost its former significance as a center of science and culture. Mosques and madrasahs here fell into decay. Educational institutions were of two types: primary school - maktab and higher - madrasah.

In maktabs, which were usually at mosques, the teachers were imams. Here they taught to read the Koran. In special schools - korikhona - students memorized the Koran and received the title of kori the reader of the Koran.

During their studies at the madrasah, they studied Arabic literacy and writing, the interpretation of the Koran, and by the middle of the 19th century. the lists of students in the Bukhara madrasah numbered from 9 to 10 thousand people. Madrasahs and mosques were economically independent, they had huge vakuf possessions, the income from which reached 5 million tanga. Some of them were used to pay teachers and scholarships for students. These expenses were controlled by one of the mudarris. Teachers who passed the annual exam at the madrasah received a special lifetime monetary scholarship - dakhyak.

Despite the difficult economic situation of the population, Bukhara remained the center of knowledge and arts. The outstanding Uzbek poet and thinker Ahmad Donish (1827-1897), a writer, philosopher and educator, lived and worked in Bukhara. He was born in Karshi and lived in Bukhara. In 1857, with the embassy of the Emir of Bukhara, Nasrullah visited Moscow and St. Petersburg. Traveled through the cities of Russia.
Ahmad Donish was the spokesman for the progressive ideas of the time. His works were directed against the established order. Ahmad Donish was one of the most significant personalities in Central Asia of this period. He was a versatile talented person - a doctor, poet, musician, artist, astronomer, scientist and calligrapher. Ahmad Donish is the founder of the educational movement. As a historian, he clearly saw the insoluble social issues of his time and actively intervened in the political affairs of the country. In his works "Risola" ("Treatise") and "A Brief History of the Mangyt Emirs of Bukhara" he subjects the history of the reign of the Mangyt emirs of Bukhara to sharp and merciless satire. A number of important data contained in his works illuminate many historical events in a new way. A. Donish opposes the unlimited power of the monarch, proposing to create a state council. In the "Treatise", the main attention is paid to the events of the reign of Emir Muzaffar (1860-1885) and the beginning of the reign of Emir Abdullakhan (1885-1910), i.e. events that unfolded in front of the author himself and which he witnessed. Much attention is paid to the military offensive of tsarism in Central Asia, the conquest of Jizzakh and Samarkand. Ahmad Donish boldly spoke out with new political convictions, breaking the old traditions of official history, and laid the foundations for a new progressive direction in the social thought of his time. Ahmad Donish saw the main force of the country's progressive movement in the education of the people. He criticized the rule of the Bukhara emir, the idle life of the wealthy and the highest clergy. Every person, A. Donish said, must work and live on the means received from his own labor. He called for learning and mastering knowledge.

\section{Conclusion}

Thus, in Bukhara in the second half of the XIX - early $\mathrm{XX}$ centuries. a special cultural life was formed, 
CURRENT RESEARCH JOURNAL OF PHILOLOGICAL SCIENCES 2(12):

108-112, December 2021

DOI: https://doi.org/10.37547/philological-crjps-02-12-23

ISSN 2767-3758

(C2021 Master Journals

Crossref do

Accepted15 ${ }^{\text {th }}$ December, 2021 \& Published 20 th December, 2021

which had a progressive democratic direction. National traditions, created by many generations of talented craftsmen, were preserved and creatively developed.

\section{REFERENCES}

1. Ахмедова 3. А., Турсунов К. С. Интеграционный процесс в рамках Европейского союза //Наука, техника и образование. - 2020. - №. 5 (69). - С. 49-52.

2. Ахмедова 3. А. Астрономические взгляды Ахмада Дониш //Вестник науки и образования. - 2018. - №. 11 (47).

3. Ахмедова 3. A. HUMAN BEING IN THE WORKS OF MEDIEVAL THINKERS //Новый день в медицине. - 2020. - №. 4. - С. 115118.

4. Ахмедова 3. А. ХІХ АСРНИНГ ИККИНЧИ ЯРМИДА ТУРКИСТОН ЎЛКАСИ МАДАНИЯТИ //ВЗГЛЯД В ПРОШЛОЕ. 2021. - T. 4. - №. 7.

5. Сагикызы А., Шуршитбай М., Ахмедова 3. UPBRINGING AND EDUCATION AS FACTORS OF HUMAN CAPITAL DEVELOPMENT //Адам әлемі. - 2021. - Т. 88. - №. 2. - С. 1825.

6. Akhmedova Z. A. THE ROLE OF TEACHING PHILOSOPHY IN MEDICAL UNIVERSITY //Наука, техника и образование. - 2021. №. 6. - C. 44-48.

7. Ахмедова 3. A. HUMAN BEING IN THE WORKS OF MEDIEVAL THINKERS //Новый день в медицине. - 2020. - №. 4. - С. 115118.

8. Azizovna A. Z. ROLE AND SIGNIFICANCE OF PHILOSOPHY IN THE LIFE OF SOCIETY //Наука, техника и образование. - 2020. №. 11 (75).

9. Ахмедова 3. А., Чориева М. А. ТРУД АХМАДА ДОНИША «ИСТОРИЯ МАНГИТСКИХ ГОСУДАРЕЙ» КАК ЦЕННЫЙ
ИСТОЧНИК ПО ИСТОРИИ БУХАРСКОГО ХАНСТВА ВТОРОЙ ПОЛОВИНЫ XVIIIПЕРВОЙ ПОЛОВИНЫ ХІХ ВВ //Наука, техника и образование. - 2020. - №. 11 (75).

10. Akhmedova Z. A. Astronomical views of Ahmad Donish //Bulletin of Science and Education. - 2018. - №. 11. - C. 47.

11. Hamdamov B. K., Temirova S. V. FROM THE HISTORY OF BUKHARA FOLK MEDICINE //CURRENT RESEARCH JOURNAL OF PHILOLOGICAL SCIENCES (2767-3758). 2021. - T. 2. - №. 12. - C. 52-55.

12. Чориева М. А. Экономика и денежное обращение (монеты) в Бухарском эмирате при мангытах (на рубеже 19-20 веков) //Наука, техника и образование. - 2020. №. 5 (69). - С. 53-56.

13. Чориева М. А. Историография жизни и политической деятельности последнего мангытского эмира Сейида Алимхана //Наука, техника и образование. - 2018. №. 9 (50).

14. Чориева М. А. СОЦИАЛЬНОЭКОНОМИЧЕСКОЕ, ПОЛИТИЧЕСКОЕ ПОЛОЖЕНИЕ БУХАРСКОГО ЭМИРАТА В КОНЦЕ ХІХ ВЕКА //Наука, техника и образование. - 2020. - №. 11 (75).

15. Ахмедова 3. А., Чориева М. А. ТРУД АХМАДА ДОНИША «ИСТОРИЯ МАНГИТСКИХ ГОСУДАРЕЙ» КАК ЦЕННЫЙ ИСТОЧНИК ПО ИСТОРИИ БУХАРСКОГО ХАНСТВА ВТОРОЙ ПОЛОВИНЫ XVIIПЕРВОЙ ПОЛОВИНЫ ХІХ ВВ //Наука, техника и образование. - 2020. - №. 11 (75).

16. ECONOMY C. M. A., CIRCULATION M. IN THE BUKHARA EMIRATE AT THE MANGYT (AT THE BORDER OF THE 19-20 CENTURIES) //Science, technology and education. - 2020. - №. 5. - C. 69.

17. Chorieva M. A. Historiography of the life and 
CURRENT RESEARCH JOURNAL OF PHILOLOGICAL SCIENCES 2(12):

108-112, December 2021

DOI: https://doi.org/10.37547/philological-crjps-02-12-23

ISSN 2767-3758

(C2021 Master Journals

Crossref $\mathbf{d}$

Accepted15 ${ }^{\text {th }}$ December, 2021 \& Published 20 th December, 2021

political activities of the last Mangyt emir, Seyid Alimkhan //Science, technology and education. - 2018.

18. MA C. EKONOMIKA I DENEZHNOYe OBRASHCHENIYe (MONETY) V BUKHARSKOM EMIRATE PRI MANGYTAKH (NA RUBEZHE 19-20 VEKOV). - 2020.

19. MA C. Istoriografiya zhizni i politicheskoy deyatel'nosti poslednego mangytskogo emira Seyida Alimkhana. - 2018.

20. Choriyeva M. A. HISTORY OF CREATION" SHAH-NAME" FIRDOUSI //CURRENT RESEARCH JOURNAL OF PHILOLOGICAL SCIENCES (2767-3758). - 2021. - T. 2. - №. 12. - C. 45-48.

21. МА Чориева РАЗВИТИЕ БАНКОВСКОГО ДЕЛА В БУХАРСКОМ ЭМИРАТЕ (19-20 ВВ)Новый день в медицине, 2020. С. 733-735

22. Akhmedova Z. A. HEALTHY LIFESTYLE AS THE KEY TO HEALTH //SCIENCE AND WORLD. - 2013. - C. 21.

23. Ахмедова 3. А., Аннамуратов Ш. La méthodologie traditionnelle et directe d'enseignement des langues étrangères //Молодой ученый. - 2017. - №. 24-2. - С. 16-17.

24. Ахмедова 3. A. HEALTHY LIFESTYLE AS THE KEY TO HEALTH //Наука и мир. - 2018. - T. 2. - №. 4. - C. 21-22.

25. Akhmedova Z. A. THE ROLE OF TEACHING PHILOSOPHY IN MEDICAL UNIVERSITY //Наука, техника и образование. - 2021. №. 6. - C. 44-48.

26. Akhmedova Z. A. PHILOSOPHY OF THE FIRST JADID AHMAD MAHDUM DONISH //CURRENT RESEARCH JOURNAL OF PHILOLOGICAL SCIENCES (2767-3758). 2021. - T. 2. - №. 12. - C. 41-44.

27. Турсунов К. Швейцария: оценки хода государственного и общественного строительства в независимом Узбекистане //Fuqarolik jamiyati.
Гражданское общество. - 2013. - Т. 10. №. 3. - С. 83-86.

28. Турсунов К. Германия: университетские исследования формирования гражданского общества в Узбекистане //Fuqarolik jamiyati. Гражданское общество. - 2009. - Т. 6. - №. 2. - С. 77-80.

29. Турсунов К. Великобритания: изучение опыта формирования основ гражданского общества в Узбекистане //Fuqarolik jamiyati. Гражданское общество. - 2011. T. 8. - №. 3. - C. 89-92.

30. Турсунов К. ЛАТВИЯ: ОЦЕНКИ РЕАЛИЗАЦИИ ГОСУДАРСТВЕННОЙ МОЛОДЕЖНОЙ ПОЛИТИКИ В НЕЗАВИСИМОМ УЗБЕКИСТАНЕ //Fuqarolik jamiyati. Гражданское общество. - 2014. - Т. 11. - №. 1. - С. 61-64.

31. Турсунов К., Бафоев $\Phi$. К вопросу становления, функционирования и развития парламентской оппозиции //Fuqarolik jamiyati. Гражданское общество. - 2008. - Т. 5. - №. 1. - С. 53-58.

32. Турсунов К. БЕЛЬГИЯ: ОСВЕЩЕНИЕ ОПЫТА ФОРМИРОВАНИЯ ОСНОВ ГРАЖДАНСКОГО ОБЩЕСТВА В УЗБЕКИСТАНЕ //Fuqarolik jamiyati. Гражданское общество. - 2010. - Т. 7. - №. 2. - C. 91-94.

33. Tursunov K. S. EUROPE AND THE COMMONWEALTH OF INDEPENDENT STATES //Наука, техника и образование. 2021. - №. 6. - C. 42-44.

34. Sodikovich T. K. HISTORY OF THE BUKHARA STATE MEDICAL INSTITUTE NAMED AFTER ABU ALI IBN SINO //Наука, техника и образование. - 2020. - №. 11 (75).

35. Tursunov Q. S. NEW UZBEKISTAN AND ELECTION LEGISLATION //CURRENT RESEARCH JOURNAL OF PHILOLOGICAL SCIENCES (2767-3758). - 2021. - T. 2. - №. 12. - C. 49-51. 